\title{
6. Security in Southern Highlands Province
}

\author{
Siale Diro
}

This chapter is intended to give a background to the security situation in Southern Highlands Province (SHP) and to outline the security mission for the 2007 election and its objectives. In so doing, it will look at the security force composition, its pre-election operations, the conduct of the election, and postelection operations. Finally, it will reflect on the strengths and weaknesses of the security operations in the province and make some recommendations for the future.

The study is based on my observations and experience as commander of the Papua New Guinea Defence Force (PNGDF) contingent in SHP and deputy commander of special police operations.

\section{Background}

Any analysis of the election in SHP must be cast against a background of the particular challenges that the province as a whole poses for security operations. SHP is the largest Highlands province and has the biggest populationapproximately 700,000 people. The province is rich in resources and contributes over 40 percent of the national economy, with the Kutubu District alone producing K11 million per day.

At the same time, SHP has the highest number of illegal weapons in the country and has experienced major breakdowns in law and order.

In the 2002 election, 'failed elections' were declared in six of the open electorates, requiring supplementary elections in 2003. By 2006 the generalized breakdown in law and order, combined with corrupt governance, saw the declaration by the national government of a state of emergency (SOE) in SHP on 15 August 2006. Subsequent court action was taken by the then provincial governor, Hami Yawari, which led to the Supreme Court nullifying the SOE in February 2007.

In the lead-up to the election, primarily due to the economic and security issues, there were grave concerns for the conduct of the election in SHP. The nation could not afford another failed election in 2007. Consequently, the national 
government introduced special police operations (SPO) in SHP on 1 March 2007 to maintain the progress made by the SOE and prepare the province for the elections.

In 2007 the Papua New Guinea Electoral Commission (PNGEC) took the important step of 'front loading' what were seen as likely problem areas for the 2007 election. This involved scheduling SHP to be the first province to go to the polls.

\section{The special police operations mission}

The mission statement for the SPO was to assist the electoral commission by providing security for NATEL 07 (National Election 2007), in order for the national government to conduct a peaceful, fair and successful national election.

The objectives were:

- security, peace and good order, removal of illegal weapons

- restoration of government services in SHP

- peaceful and successful conduct of national elections in SHP

- post-election stability in SHP.

In the pre-election period the force was composed of 200 regular police men and women and 150 PNGDF personnel, comprising 90 infantry (security), 40 engineers with plant and equipment (restoration), and 20 support staff (medics, military police, communications personnel, etc). During the polling period this presence was bolstered by the concentration of security forces from other Highlands provinces, including some 2000 police and 500 PNGDF personnel. For the counting period in SHP the security presence reverted back to pre-election strength, providing a smaller contribution to polling in other Highlands provinces so as to maintain a high level of presence.

\section{Conduct and rules of engagement}

As this was a small force with limited resources, operations required strict adherence to the rules of engagement, backed by strong discipline. Its operations were based on a high level of public law and order awareness conducted through the media, and an effective command and control mechanism. This was supported by a dedicated public relations strategy and, importantly, effective inter-agency cooperation. 
It was a 'balanced force' with appropriate posture (graduated response), intended to provide a firm but fair and neutral approach, remembering that the trust and confidence of the people is the centre of gravity.

\section{Pre-election operations}

Pre-election operations had a major focus on two aspects: security and restoration. Improving the security climate involved:

- physical patrols and a show of presence throughout the province

- law and order awareness in the media

- swift and decisive action and discipline - or 'zero tolerance' - towards crime.

This was successful in facilitating greater freedom of movement throughout the province. As a result, business and economic activity picked up and public confidence was boosted. It was also evident that the new limited preferential voting system had relieved the tension. The end result was that during the preelection period, the physical conditions were set for a peaceful election.

The restoration aspect of pre-election operations involved PNGDF engineers and others working to restore:

- the Kiburu to Mendi road

- the Mendi airport fencing

- culverts and earthworks for churches

- Momei oval counting centre fencing.

This period also saw engineer reconnaissance in Nipa, Upper Mendi and Kagua.

The pre-election period involved coordination with the provincial election steering committee which was chaired by the provincial administrator, $\mathrm{Mr}$ William Powi. That committee consisted of the electoral commission, police, Defence, Correctional Services, and church, business and community leaders. The committee commenced regular meetings in April 2007 and was very effective in coordinating the inter-agency effort, in line with the 'whole-of-government' approach to national elections. The committee made many critical decisions, such as centralizing counting in Mendi.

Finally, these measures required spiritual support. Southern Highlands Province has an extensive Christian network, with more than 30 Christian denominations. The people of SHP are tired of violence and corruption and it was considered time to encourage the spiritual community to take the lead in asking God to bring peace into the province. 
The spiritual measures commenced with a prayer breakfast with the SHP 'Body of Christ' in Mendi on 12 May. It culminated with a spiritual rally to invite the Holy Spirit into SHP. This rally was held under the theme of 'peaceful elections' and the security force provided logistic support (including transport, fuel, rations, etc.) and combined youth worship groups from the PNGDF's Taurama and Igam Barracks. The rally was held across SHP from 28 May to 3 June 2007 and thousands attended in Tari, Nipa, Ialibu and Mendi.

\section{Conduct of elections: The polling period}

SHP was the first Highlands province in the country to vote when the polls opened on 30 July. At that time, 2500 security forces personnel were deployed (the force was moved to Enga after polling in SHP was complete).

With 862 polling sites, the election was always going to be a logistics nightmare. This, combined with the fact that SHP is a vast province with rugged terrain and bad weather, compounded the challenges faced by the security forces.

Police and Correctional Services provided security for polling teams, while Defence and police mobile squads provided patrols, escorts and vital asset protection. The whole operation required extensive inter-agency liaison and coordination.

Due to bad weather, polling had to be extended in some parts and in this respect the electoral commissioner reacted in timely manner to extend the polling period.

Despite late arrival of polling materials, and the challenges noted above, polling generally went well and the province was peaceful during polling. In suspected trouble spots such as Nipa and Upper Mendi, people exercised their democratic right free of violence.

\section{Conduct of the election: The count}

As stated above, counting for the province was centralized at the Momei Oval counting centre in Mendi. The PNGDF maintained an inner cordon, which protected the ballot boxes between the airport and the counting centre, and police and CIS maintained an outer cordon of road blocks and crowd control. Security was very tight and was successful in keeping the threat off-balance. The centre was designed for maximum transparency and counting was conducted in a peaceful manner in what was almost a festive atmosphere. 
Strict discipline ensured that security forces stuck to their designated roles and did not interfere with the electoral process. The SPO command was detached from the counting centre.

By 29 July 2007 the people of SHP had peacefully elected their nine members into the eighth national parliament.

\section{Post-election operations}

At the end of July, the SPO was ordered to withdraw by mid August. This decision had a significant impact on operations, as people of SHP were expecting us to stay until 31 August. In response, the SPO conducted immediate awareness across the province to alleviate people's fears and set the conditions for withdrawal. The decision brought forward strategic lift and extraction plans.

The SPO formal presence culminated in a farewell parade which was held on the 11 August 2007 in Mendi. At this event the people were encouraged to maintain peace and a general warning was communicated to potential troublemakers. The farewell also involved a weapons destruction ceremony at which PNGDF engineers destroyed five Mag 58s, nine SLRs, eleven M16s, fifteen AR15s, 86 factory-made shot guns, and 161 homemade weapons. The destroyed weapons were sealed in drums, taken to Lae, and dumped at sea.

The public took part in the ceremony, which was a symbolic gesture of a new future for SHP, safe and free of guns. The event also involved a prayer luncheon in a gathering with the provincial Body of Christ. Those at the luncheon thanked God for his blessings. It was a fitting spiritual closure to the SPO. By 15 August, all Defence personnel were withdrawn from SHP and soon after, all SPO police were withdrawn.

On 29 August, SHP Governor, Anderson Agiru and the eight SHP Open members - James Marabe, Isaac Joseph, Francis Potape, Philemon Embel, John Kekeno Kelewa, Peter O'Neill, James Lagea and Francis Awesa-walked together from the airport to Momei Oval, where they addressed the people of SHP.

\section{Assessing the SPO}

\section{Strengths}

It was clearly apparent that the new limited preferential voting system played a role in significantly reducing the security contingency. This, the whole-of- 
government approach, a strong national will towards fairness, and excellent inter-agency cooperation through the provincial election steering committee, were all major strengths in the 2007 election in SHP.

Public relations, spiritual linkage, and awareness to develop the 'trust and confidence of the people', created an important enabling environment.

From a logistic and administrative perspective, the timely allocation of troops' allowances was also a strength, as was the flexibility of the force. This permitted 'front loading' in problem areas and allowed for economy of effort and concentration of force.

The presence of the PNGEC's legal adviser, Professor John Nonggorr, on location provided enhanced situational awareness. The improved command, control and cooperation of the Royal Papua New Guinea Constabulary was also a contributing factor.

Some of these strengths resulted directly from difficult PNGDF reform decisions, in line with the commander's vision of a smarter and operationally focused force. Through Joint Forces Headquarters, the PNGDF's air, sea and land assets were deployed extensively to support the elections, and command and control of operations was far more effective and responsive than in the past. There was also '24/7' monitoring. The PNGDF has now commenced the 'build-up phase' of its reform process and the success in 2007 justifies continued support for the reforms.

\section{Weaknesses}

There were, however, weaknesses that hindered the success of the operation and need to be addressed in the future. These were mostly in the areas of:

- communications

- riot control equipment

- postal voting

- the common roll

- delivery of election materials and payment of election officials' entitlements.

To address these weaknesses the following recommendations are put forward to improve the security mobilization at the next election:

- extend security pre-deployment to problem areas

- formalize whole-of-government and inter-agency arrangements (training, etc)

- improve communications 
- 'front load' problem areas

- purchase appropriate equipment (specifically riot gear).

Overall, however, the whole-of-government approach and strong national will created the resource and psychological platform for improved security in SHP during the 2007 election. 